Acta Protozool. (2018) 57: 95-106

www.ejournals.eu/Acta-Protozoologica

doi:10.4467/16890027AP.18.009.8983

PROTOZOOLOGICA

\title{
Redescription of Dexiotricha colpidiopsis (Kahl, 1926) Jankowski, 1964 (Ciliophora, Oligohymenophorea) from a Hot Spring in Iceland with Identification Key for Dexiotricha species
}

\author{
Zhishuai QU ${ }^{1,2}$, René GROBEN, Viggó MARTEINSSON ${ }^{3,4}$, Sabine AGATHA ${ }^{5}$, Sabine FILKER ${ }^{6}$, \\ Thorsten STOECK ${ }^{1}$
}

${ }^{1}$ Department of Ecology, University of Kaiserslautern, Kaiserslautern, Germany; ${ }^{2}$ Institute of Evolution \& Marine Biodiversity,
Ocean University of China, Qingdao, PR China; ${ }^{3}$ Exploration \& Utilization of Genetic Resources, Matis ohf., Reykjavik, Iceland;
${ }^{4}$ Faculty of Food Science and Nutrition, University of Iceland, Reykjavík, Iceland; ${ }^{5}$ Department of Biosciences, University of
Salzburg, Salzburg, Austria; ${ }^{6}$ Department of Molecular Ecology, University of Kaiserslautern, Kaiserslauten, Germany

Abstract. We isolated an encysted ciliate from a geothermal field in Iceland. The morphological features of this isolate fit the descriptions of Dexiotricha colpidiopsis (Kahl, 1926) Jankowski, 1964 very well. These comprise body shape and size in vivo, the number of somatic kineties, and the positions of macronucleus and contractile vacuole. Using state-of-the-art taxonomic methods, the species is redescribed, including phylogenetic analyses of the small subunit ribosomal RNA (SSU rRNA) gene as molecular marker. In the phylogenetic analyses, D. colpidiopsis clusters with the three available SSU rRNA gene sequences of congeners, suggesting a monophyly of the genus Dexiotricha. Its closest relative in phylogenetic analyses is D. elliptica, which also shows a high morphological similarity. This is the first record of a Dexiotricha species from a hot spring, indicating a wide temperature tolerance of this species at least in the encysted state. The new findings on D. colpidiopsis are included in a briefly revision of the scuticociliate genus Dexiotricha and an identification key to the species.

Key words: Dexiotricha; hot spring; morphology; phylogeny; SSU rRNA gene

\section{INTRODUCTON}

Discoveries and descriptions of ciliates have been continuously and systematically carried out in "common" habitats worldwide, such as soil, freshwater, and marine waters (e.g., Kahl 1931; Dragesco and Dragesco-Kernéis 1986; Foissner et al. 1994; Song et

Address for correspondence: Thorsten Stoeck: Room 14/147, Erwin-Schroedinger-Str. 14, University of Kaiserslautern, Kaiserslautern 67663, Germany; Tel./Fax: 0049 631-205-2502; E-mail: stoeck@rhrk.uni-kl.de al. 2009; Liu et al. 2017). In contrast, relatively few studies focused on ciliates in extreme habitats, including for example extremely cold regions (Agatha et al. 1990, 1993; Petz et al. 1995; Roberts et al. 2004; Xu et al. 2016), hot springs (Noland and Gojdics 1967; Kahan 1969, 1972), hydrothermal vents in the deep ocean (Small and Gross 1985; Kouris et al. 2007), and hypersaline environments (Oren 2002; Foissner 2012; Foissner et al. 2002, 2014).

The term "extreme" is commonly used to describe habitats that are detrimental to most organisms (Hu 2014). Among the extreme habitats, geothermal 
environments hold a special position. Because of their physico-chemical conditions, they are considered analogues for early Earth conditions and also as terrestrial analogue sites with assumed past or present geological, environmental or biological conditions of a celestial body (Djokic et al. 2017). The only lifeforms in such extreme environments are usually unicellular with specific adaptations, which might be evolutionary relics (Hu 2014). Thus, microbes from such extreme environments are highly interesting candidates to inspire evolutionary theory or serve as models for extraordinary adaptation strategies (Filker et al. 2017).

Therefore, samples from geothermal fields (hot springs) in Iceland had been analysed for the presence of ciliated protists. In one of these samples, an encysted ciliate occurred that developed surprisingly high abundances under common culture conditions; the species was identified as Dexiotricha colpidiopsis (Kahl, 1926) Jankowski, 1964. Because the original description of the species lacks many details and does not fulfil contemporary requirements (Warren et al. 2017), it is redescribed here, using state-of-the-art methods, providing its first SSU rRNA gene sequence. The new findings are included in a revision of the genus Dexiotricha and an identification key based on morphological characteristics of its species.

\section{MATERIALS AND METHODS}

\section{Sampling}

Samples (sapropel and indigenous water) with resting cysts of the species were taken from a microbial mat in a geothermal field in Iceland close to the Hellisheiðarvirkjun geothermal power station, ca. $30 \mathrm{~km}$ east of the city of Reykjavik $\left(64^{\circ} 01^{\prime} 11.5^{\prime} \mathrm{N}\right.$, $21^{\circ} 23^{\prime} 50.5^{\prime \prime} \mathrm{W}$; Fig. 1), in July 2017 . The water temperature was ca. $87^{\circ} \mathrm{C}$ near the spring and ca. $75^{\circ} \mathrm{C}$ at the sampling site; the $\mathrm{pH}$ was 7.95 and conductivity was $204 \mu \mathrm{Si} / \mathrm{cm}^{2}$. Trace elements in the water from the sampling site were analysed by ICP-MS (inductively coupled argon plasma mass spectroscopy) on an Agilent 7500ce, using the modified NMKL 186, 2007 method (NordVal International, Denmark) (Table 1).

\section{Cultivation}

Enrichment cultures of the ciliate were established at room temperature (about $20^{\circ} \mathrm{C}$ ) by adding a wheat grain to the originally collected sample. Pure cultures were obtained by successively transferring the ciliates from the enrichment culture to a mixture of original water (filtered through $0.65 \mu \mathrm{m}$-membranes to maintain indigenous bacteria) and Volvic water. Again a wheat grain supported the growth of bacteria as food source for the ciliate. The species is now maintained entirely in Volvic water with a wheat grain at room temperature.
Table 1. Ion concentrations in the water at the sampling site.

\begin{tabular}{lc}
\hline Ion & Concentration $(\mathrm{mg} / \mathrm{l})$ \\
\hline $\mathrm{Cl}^{-}$ & not detectable \\
$\mathrm{Na}^{+}$ & 26.83 \\
$\mathrm{~K}^{+}$ & 3.45 \\
$\mathrm{Ca}^{2+}$ & 10.93 \\
$\mathrm{Mg}^{2+}$ & 6.38 \\
$\mathrm{Fe}^{2+}$ & 6.67 \\
$\mathrm{P}$ & 51.38 \\
\hline
\end{tabular}

\section{Morphological studies and protargol-staining}

Living cells collected from pure cultures were observed, using an oil immersion objective and differential interference contrast microscopy (Zeiss Axioplan). Wilbert's (1975) protargol-staining method was applied to reveal the ciliature and nuclear apparatus; the protargol was produced, mainly following the protocol of Pan et al. (2013). The dry silver nitrate method following the procedure in Foissner (2014) was used to show the position of the contractile vacuole pore. Morphometric measurements were made at $1,000 \times$ magnification. Illustrations of live specimens are based on photomicrographs and notes, while those of protargol-stained cells were made by means of a drawing device.

\section{Terminology and classification}

Terminology follows Fan et al. (2014), and systematics follows Gao et al. (2016).

\section{DNA extraction, PCR, and sequencing}

Ten cells were carefully selected from the pure culture and washed in distilled water prior to DNA extraction. The genomic DNA was extracted, using the DNeasy Tissue Kit (Qiagen, Hilden, Germany), following the manufacturer's instruction for animal tissues. The SSU rRNA gene for phylogenetic analyses was amplified, using Phusion Taq (NEB, MA, USA) as well as the primers Euk82 (5'-GAA[AGT]CTG[CT]GAA[CT]GGCTC-3') (López-Garcia et al. 2001) and U1517R (5'-ACGGCTACCTTGTTACGACTT-3') (Stoeck et al. 2006). Parameters of the PCR were as follows: $30 \mathrm{~s}$ initial denaturation at $98^{\circ} \mathrm{C} ; 30$ identical cycles of denaturation at $98^{\circ} \mathrm{C}$ for $10 \mathrm{~s}$, annealing at $56^{\circ} \mathrm{C}$ for $1 \mathrm{~min}$, extension at $72^{\circ} \mathrm{C}$ for $45 \mathrm{~s}$; and a final extension at $72^{\circ} \mathrm{C}$ for $2 \mathrm{~min}$. The PCR product was purified with the MiniElute kit (Qiagen, Germany) and cloned into a vector, using the PCR cloning kit with the pMiniT vector (NEB, Germany). Sequencing was performed with the Big Dye Terminator Kit (Applied Biosystems, FosterCity, CA) on an ABI 3730 automated sequencer.

\section{Phylogenetic analyses}

In addition to the new SSU rRNA gene sequence of Dexiotricha colpidiopsis, sequences of 63 further species obtained from the GenBank database (accession numbers see in Fig. 4) were used in the phylogenetic analyses. Three species, Nolandia orientalis, Prorodon ovum, and Placus salinus, were used as out-group references. 


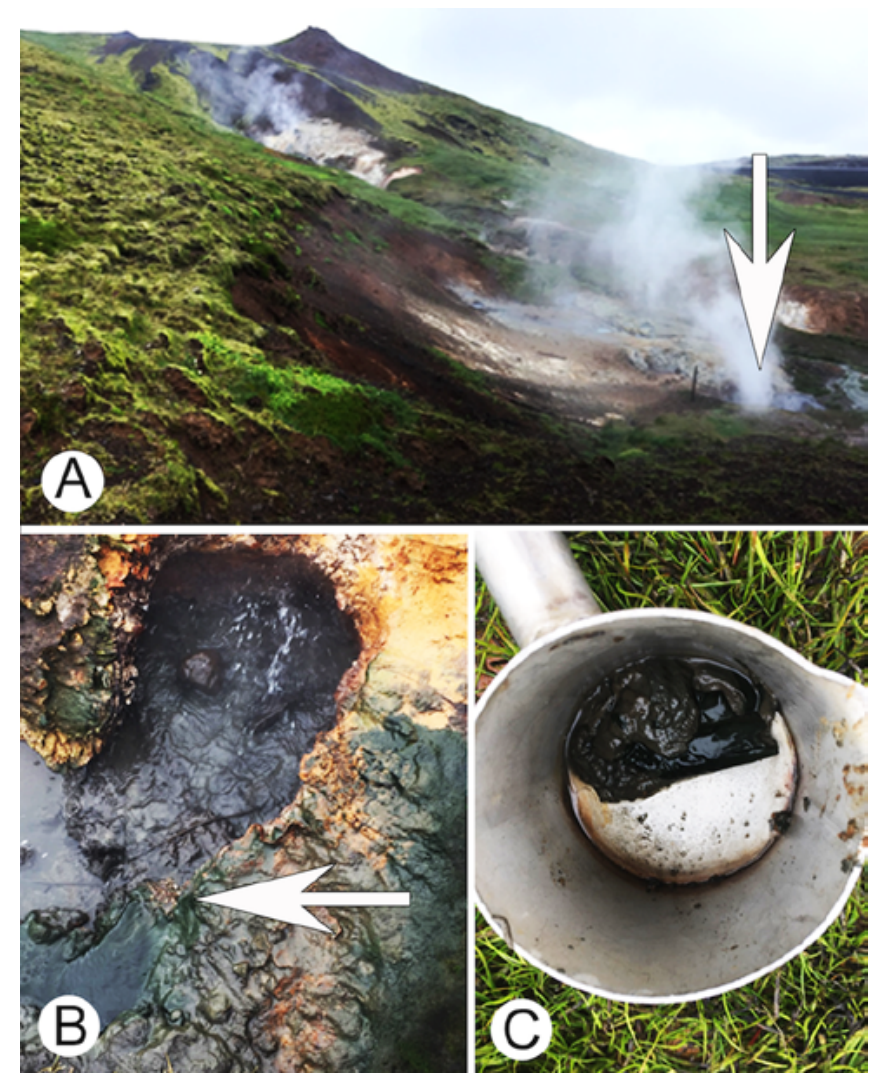

Sequences were aligned, using the MUSCLE program package on the European Bioinformatics Institute web server (http://www.ebi. ac.uk). The resulting alignment was then edited manually with trimming both ends, resulting in a matrix of 1,720 nucleotide positions. A Maximum-likelihood (ML) tree was constructed with 1,000 bootstrap replicates by means of RAxML-HPC2 v. 8.2.10 (Stamatakis 2014) on the CIPRES Science Gateway (Miller et al. 2010) with the optimal model GTR $+\mathrm{I}+\Gamma$ selected by Modeltest v.3.4 (Posada and Crandall 1998). A Bayesian inference (BI) analysis was run, using the MrBayes 3.2.6 package on XSEDE (Ronquist and Huelsenbeck 2003) on the CIPRES Science Gateway with the model GTR + I + $\Gamma$ as selected by MrModeltest 2.2 (Nylander 2004). Markov Chain Monte Carlo (MCMC) simulations were run for a million generations by a sample frequency of every 100th generation, with the first $25 \%$ discarded as burn-in. The number of chains to run was four. All data are available from the authors upon request.

\section{4}

Fig. 1. Sampling site in hot spring in Iceland $(\mathbf{A}, \mathbf{B})$ and sapropel sample (C).

Table 2. Morphometric data on Dexiotricha colpidiopsis based on protargol-stained specimens.

\begin{tabular}{|c|c|c|c|c|c|c|c|c|}
\hline Character $^{1}$ & Min & Max & $\bar{x}$ & M & SD & SE & $\mathrm{CV}$ & $\mathrm{n}$ \\
\hline Body, length & 38 & 61 & 51.5 & 51.5 & 5.86 & 0.20 & 11.4 & 30 \\
\hline Body, width & 18 & 33 & 25.6 & 25.0 & 3.50 & 0.12 & 13.7 & 30 \\
\hline Body length:width, ratio & 1.82 & 2.50 & 2.02 & 2.00 & 0.15 & 0.00 & 7.4 & 30 \\
\hline Macronucleus, length & 7 & 11 & 8.7 & 8.0 & 1.27 & 0.04 & 14.6 & 30 \\
\hline Macronucleus, width & 7 & 11 & 8.5 & 8.0 & 1.36 & 0.05 & 16.0 & 30 \\
\hline Micronucleus, diameter & 2 & 2 & 2.0 & 2.0 & 0.00 & 0.00 & 0.0 & 29 \\
\hline Anterior cell end to macronucleus, distance & 27 & 40 & 33 & 32.5 & 3.17 & 0.11 & 9.6 & 30 \\
\hline Buccal cavity, length ${ }^{2}$ & 9 & 12 & 10.1 & 10 & 0.78 & 0.03 & 7.8 & 30 \\
\hline Anterior cell end to anterior end of membrane 1 , distance & 5 & 9 & 6.3 & 6 & 0.88 & 0.03 & 13.9 & 30 \\
\hline Anterior cell end to anterior end of membrane 2, distance & 7 & 11 & 8.3 & 8 & 0.88 & 0.03 & 10.6 & 30 \\
\hline Anterior cell end to anterior end of membrane 3 , distance & 9 & 13 & 10.4 & 10 & 0.85 & 0.03 & 8.2 & 30 \\
\hline Anterior cell end to anterior end of paroral membrane, distance & 6 & 10 & 7.6 & 7 & 0.94 & 0.03 & 12.4 & 30 \\
\hline Somatic kineties including postoral kineties, number & 24 & 27 & 26.3 & 27.0 & 0.88 & 0.03 & 3.4 & 30 \\
\hline Postoral kineties, number & 3 & 3 & 3.0 & 3.0 & 0.00 & 0.00 & 0.0 & 29 \\
\hline Kinetids in SKn, number & 18 & 25 & 20.3 & 20.0 & 1.60 & 0.06 & 7.9 & 29 \\
\hline Kinetids in PK2, number & 1 & 3 & 2.9 & 3.0 & 0.44 & 0.02 & 15.4 & 29 \\
\hline
\end{tabular}

${ }^{1}$ Data are based on randomly selected, protargol-impregnated, and mounted specimens from Volvic cultured specimens. Measurements in $\mu \mathrm{m}$. CV, coefficient of variation; M, median; Max, maximum; Min, minimum; $n$, number of individuals investigated; PK2, second postoral kinety; SD, standard deviation; SE, standard error of arithmetic mean; SKn, first kinety left of oral apparatus; $\overline{\mathrm{x}}$, arithetic mean. ${ }^{2}$ Distance from anterior end of adoral membranelle 1 to proximal end of paroral membrane. 


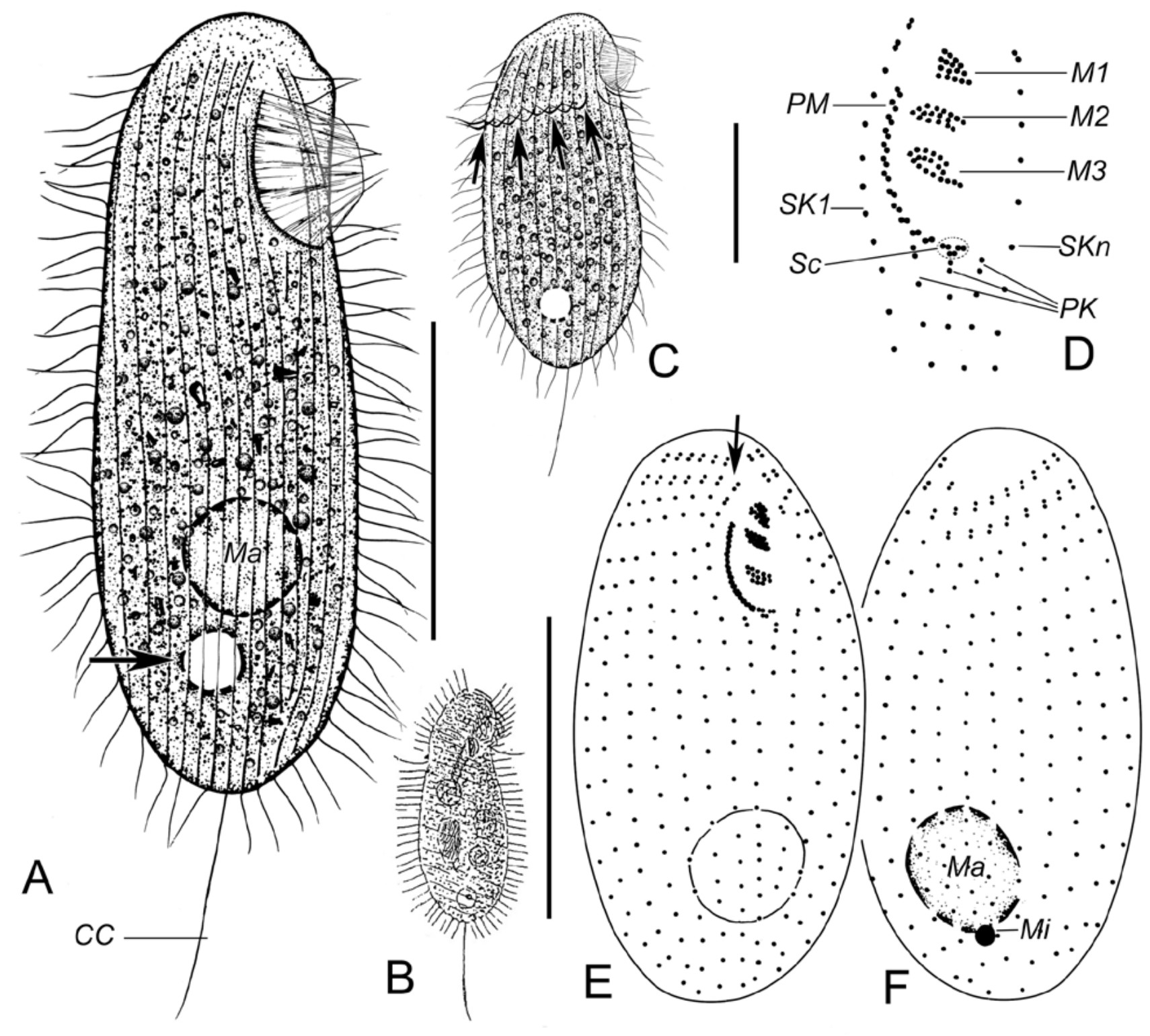

Fig. 2. Dexiotricha colpidiopsis from live (A-C) and after protargol-staining (D-F). (A) Ventrolateral view of a typical specimen showing the subterminal contractile vacuole (arrow). (B) Ventral view (from Kahl 1926). (C) Right lateral view showing the transverse row of cilia (arrows). (D) Ciliature of oral region. (E, F) Ventral and dorsal views of type specimen. CC, caudal cilium; M1-3, membranelles 1-3; Ma, macronucleus; Mi, micronucleus; PK, postoral kineties; PM, paroral membrane; Sc, scutica; SK, somatic kineties; SK1, first somatic kinety on right margin of buccal cavity; SKn, first somatic kinety on left margin of buccal cavity. Scale bars: $25 \mu \mathrm{m}$.

\section{RESULTS}

\section{Class Oligohymenophorea de Puytorac et al., 1974}

Subclass Scuticociliatia Small, 1967

\section{Order Loxocephalida Jankowski, 1980}

Family Loxocephalidae Jankowski, 1964

Genus Dexiotricha Stokes, 1885
Improved diagnosis: Cell of moderate size (35$80 \mu \mathrm{m})$, ellipsoidal to ovoidal. Anterior end unciliated, posterior end with one or several long caudal cilia. Three postoral kineties, with highly shortened middle one. Cytostome subapical, up to $20 \%$ of cell length; paroral membrane commences approximately at level of membranelle 1. Scutica near proximal end of paroral membrane. Macronucleus, micronucleus, and contractile vacuole in mid-body or posterior cell portion. 

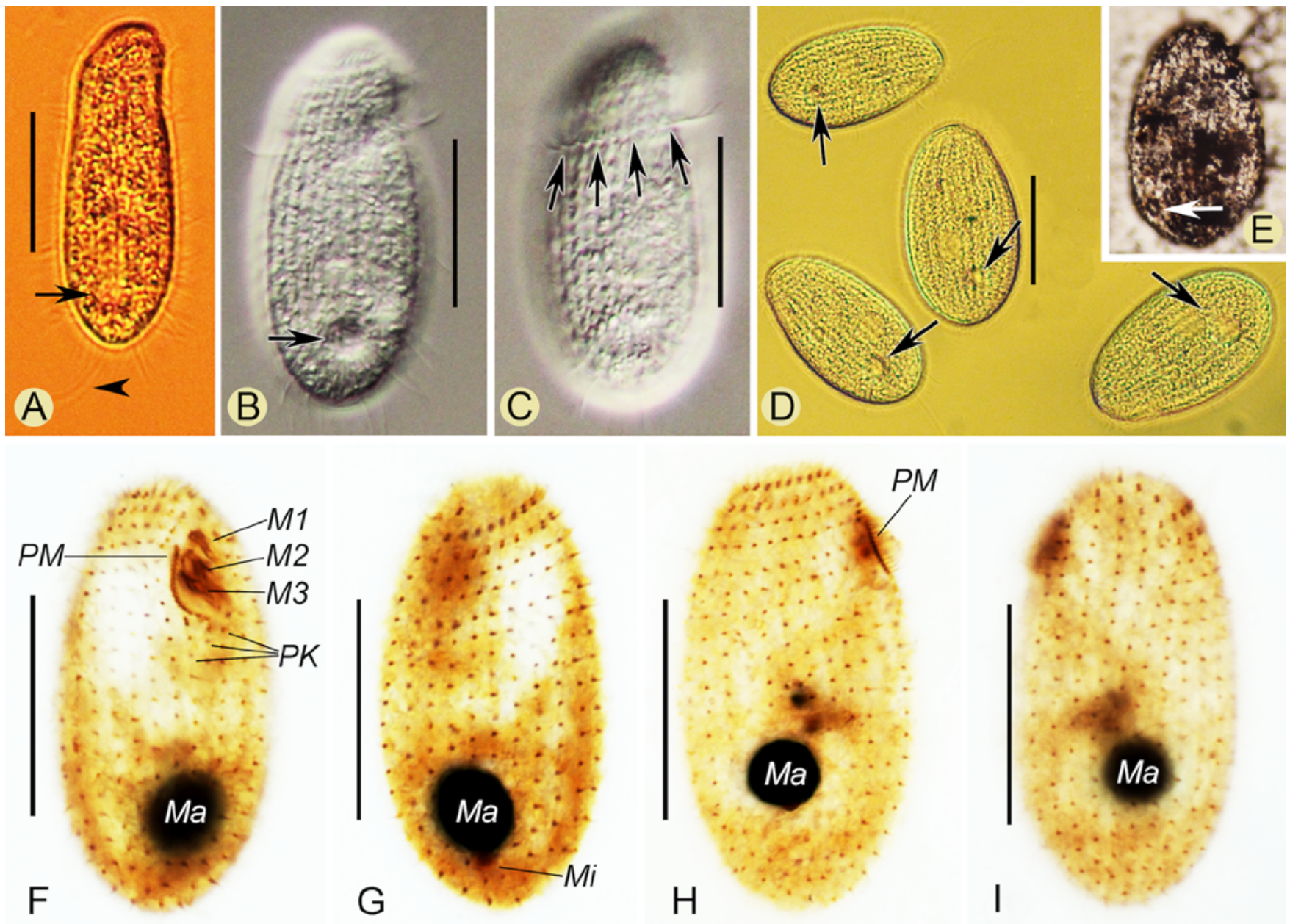

Fig. 3. Photomicrographs of Dexiotricha colpidiopsis from live (A-D; A with bright field illumination, C-D with differential interference contrast microscopy), after dry silver nitrate staining (E), and after protargol-impregnation (F-I). (A, B) Ventrolateral views showing the subterminal contractile vacuole (arrows) and the caudal cilium (arrowhead). (C) Right lateral view showing the transverse row of cilia (arrows). (D) Slightly compressed specimens showing the subterminal contractile vacuole (arrows). (E) Showing the position of the contractile vacuole pore (arrow). (F, G) Ventral and dorsal views of the type specimen. (H, I) Right and left lateral views. M1-3, membranelles 1-3; Ma, macronucleus; Mi, micronucleus; PK, postoral kinety, PM, paroral membrane. Scale bars: $25 \mu \mathrm{m}$.

Kinetids form horizontal rows in anterior third of cell, with enlarged distance between certain horizontal rows on right cell side, forming distinct transverse gaps. Extrusomes exist.

Dexiotricha colpidiopsis (Kahl, 1926) Jankowski, 1964 (Figs 2 and 3; Table 2)

1926 Loxocephalus colpidiopsis, Kahl, Arch. Protistenk., 55: 197-438.

1960 Loxocephalus enigmaticus, Vuxanovici, Stud. Cercet. Biol. 12: 353-381.

Improved diagnosis based on Kahl (1926), Jankowski (1964), and present study. Cell 38-60×
$15-24 \mu \mathrm{m}$ in size in vivo, about $38-61 \times 18-33 \mu \mathrm{m}$ after protargol-staining, ellipsoidal to elongate ellipsoidal. Macronucleus and contractile vacuole with one tube-like pore subterminal. Three adoral membranelles composed of three or four rows of basal bodies each. Scutica comprise three dikinetids. Somatic ciliature consists of 24-27 kineties including invariably three postoral kineties. One caudal cilium.

Deposition of neotype specimens. One neotype slide with protargol-stained specimens has been deposited in the Biologiezentrum of the Oberösterreichische Landesmuseum in Linz (LI), Austria, reg. no. 2018/2. Relevant specimens have been marked by black ink circles on the coverslip. 
Morphological description. Cell $38-60 \times 15-$ $20 \mu \mathrm{m}$ in size in vivo, and $38-61 \times 18-33 \mu \mathrm{m}$ after protargol-impregnation; ellipsoidal to elongate ellipsoidal, with protrusion in anterior left portion; length:width ratio about 3:1 in vivo, and about 2:1 after protargol staining (Figs 2A, C, 3A-C). Buccal cavity occupies about $20 \%$ of cell length, with an inconspicuous paroral membrane (Figs 2A, C). Single globular macronucleus, located in posterior third of cell, about $10 \mu \mathrm{m}$ in diameter in vivo, and about $9 \mu \mathrm{m}$ across after staining (Figs 2A, 3F-I). Micronucleus attached to macronucleus, globular, about $2 \mu \mathrm{m}$ across after protargol staining (Fig. 3G). Extrusomes indistinct, rod-shaped, size about 3-4 $\mu \mathrm{m}$ long, in whole cell periphery. Contractile vacuole subterminal (in posterior $10-20 \%$ of cell), up to $5-7 \mu \mathrm{m}$ across, with contracting frequency of about $10 \mathrm{~s}$ in Volvic culture (Figs 2A, C, 3A, B, D); pore at about posterior 20\% of cell after dry silver staining, tube-like (Fig. 3E). Cytoplasm colourless, contains numerous globular granules 1-2 $\mu \mathrm{m}$ across. Cytopyge not detected.

Somatic kineties extend in shallow furrows. Somatic cilia about $7 \mu \mathrm{m}$ long in vivo, arranged in 24-27 longitudinal kineties composed of monokinetids and two anterior dikinetids, except for postoral kineties and first kinety left of oral apparatus with only one anterior dikinetid (Figs 2D-F, 3F-I); apical cell portion unciliated. First kinety right of oral apparatus with four densely arranged kinetids at anterior end. First kinety left of oral apparatus anteriorly shortened, starting at level of anteriormost adoral membranelle (Figs 2D, E). Distances between the fourth and fifth kinetids enlarged in kineties in right side, cilia of fifth kinetids (those along posterior margin of gap) form a distinct transverse row because of their rigidity (Figs 2C, 3C). Three postoral kineties (numbered from right to left, PK1-3): PK1 commences posteriorly to paroral membrane and terminates nearly rear end; PK2 commences near scutica, distinctly shortened posteriorly, usually comprising only three kinetids (out of 30 specimens investigated, one had only one pair of dikinetids, and two had two pairs of dikinetids) (Figs 2D, E, 3F); PK3 extends from lower margin of cytostome almost to posterior cell end. Scutica located near proximal end of paroral membrane, composed of three dikinetids. One caudal cilium mobile and 20-30 $\mu \mathrm{m}$ long (Figs 2A-C, 3A).

Oral apparatus comprises three adoral membranelles (numbered from anterior to posterior, M1-3) and a paroral membrane (Figs 2D, 3F). Adoral membranelles obliquely inclined; M1 consists of four oblique rows, each comprising three to five basal bodies; M2 comprises

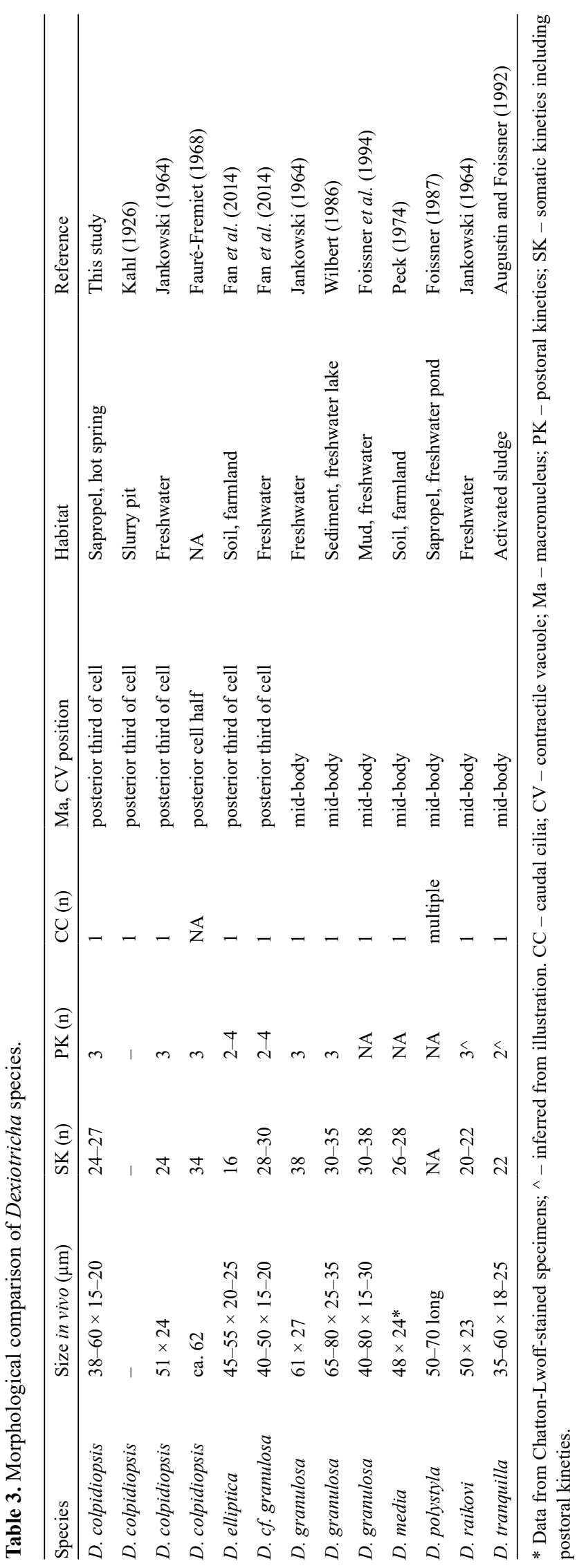


three rows, each with four to eight basal bodies; M3 composed of three rows, each consisting of five to nine basal bodies. Paroral membrane about one sixth of body length, commences at level of posterior margin of M1 and delimitates buccal cavity on the right side, roughly $\mathrm{C}$-shaped.

Ecology. The present Dexiotricha colpidiopsis was isolated as resting cysts from a hot spring at a geothermal field in Iceland. The organism survived in encysted state at $75^{\circ} \mathrm{C}$ at the sampling site and excysted and grew well at $20^{\circ} \mathrm{C}$ in the laboratory. It is also tolerant concerning the culture media (Volvic vs. water from sampling site) and the food bacteria (those in Volvic culture might deviate from those dominating in Iceland). The bacterivorous nutrition of the ciliate, makes the species relatively easy to cultivate and maintain in the laboratory. Even at very high bacterial concentrations, namely when the bacteria started forming clouds in the medium and biofilms on the surface of the medium, the organisms still grew well.

SSU rRNA gene sequence and phylogenetic placement. The SSU rRNA gene sequence of Dexiotricha colpidiopsis was deposited in the GenBank database under the accession number MG819725. The length and GC content of the SSU rRNA gene sequence are 1,660 bp and $43.25 \%$, respectively. The new sequence shows highest sequence similarity to Dexiotricha elliptica KF878932 (91.9\%; Table 4). In both ML and BI trees, $D$. colpidiopsis is sister to D. elliptica, however, with low bootstrap support $(57 \% / 0.77, \mathrm{ML} / \mathrm{BI})$. The four available Dexiotricha sequences form a monophylum with significant support from ML analysis (99\%) and full support from BI analysis (1.00) (Fig. 4).

\section{DISCUSSION}

Brief revision of genus Dexiotricha Stokes, 1885. The genus was established by Stokes (1885) with the type species Dexiotricha plagia Stokes, 1885, which probably is a junior synonym of $D$. granulosa (Kent, 1881) Foissner et al., 1994. Jankowski (1964) provided a description of the genus based on live and silverstained specimens from own observations; while more detailed information was given by Jankowski (2007). On the basis of the latter two references, we improved the genus diagnosis, adding information from our own observations.

Dexiotricha had only been recorded from freshwater, soil, and activated sludge, while not from marine or brackish waters (Table 3). The main distinguishing features of the Dexiotricha species are: (1) the number of somatic and postoral kineties; (2) the number of caudal cilia; and (3) the positions of macronucleus and contractile vacuole.

The genus currently comprises seven valid species: Dexiotricha colpidiopsis (Kahl, 1926) Jankowski, 1964 (Figs 2, 3, 5J, K); D. elliptica (Kahl, 1931) Fan et al., 2014 (Figs 5A-C); D. granulosa (Kent, 1881) Foissner et al. 1994 (Figs 5G, H); D. media Peck, 1974 (Fig. 5I); D. polystyla Foissner, 1987 (Fig. 5F); D. raikovi Jankowski, 1964 (Fig. 5L); and D. tranquilla (Kahl, 1926) Augustin \& Foissner, 1992 (Figs 5D, E). For the morphological data of these species, see Table 3. For facilitating identification, a key to the species based on morphological features is provided here.

\section{Identification key for Dexiotricha species}

1 Species with one caudal cilium

1 'Species with multiple caudal cilia

2 Contractile vacuole and macronucleus near mid-body

2 Contractile vacuole and macronucleus in posterior cell third

3 Ring-shaped cytoplasmic granules present

3' Ring-shaped cytoplasmic granules absent

4 With 16 somatic kineties

4' With 24-28 somatic kineties

4 " With about 34 somatic kineties

5 26-28 somatic kineties

5' 20-22 somatic kineties

6 Two postoral kineties

6' Three postoral kineties
D. polystyla

3

4

D. granulosa

5

D. elliptica

D. colpidiopsis

D. colpidiopsis sensu Fauré-Fremiet (1968)

D. media

6

D. raikovi

D. tranquilla 
Table 4. Similarities of the SSU rRNA genes of the four sequenced Dexiotricha species. $1=$ D. colpidiopsis; $2=$ D. elliptica; $3=$ D. granulosa; 4 = Dexiotricha sp.

\begin{tabular}{lllll}
\hline Species & D. colpidiopsis & D. elliptica & D. granulosa & Dexiotricha sp. \\
\hline 1 & - & $91.9 \%$ & $90.7 \%$ & $90.4 \%$ \\
2 & $91.9 \%$ & - & $94.3 \%$ & $92.3 \%$ \\
3 & $90.7 \%$ & $94.3 \%$ & - & $99.1 \%$ \\
4 & $90.4 \%$ & $99.1 \%$ & $92.3 \%$ & - \\
\hline
\end{tabular}

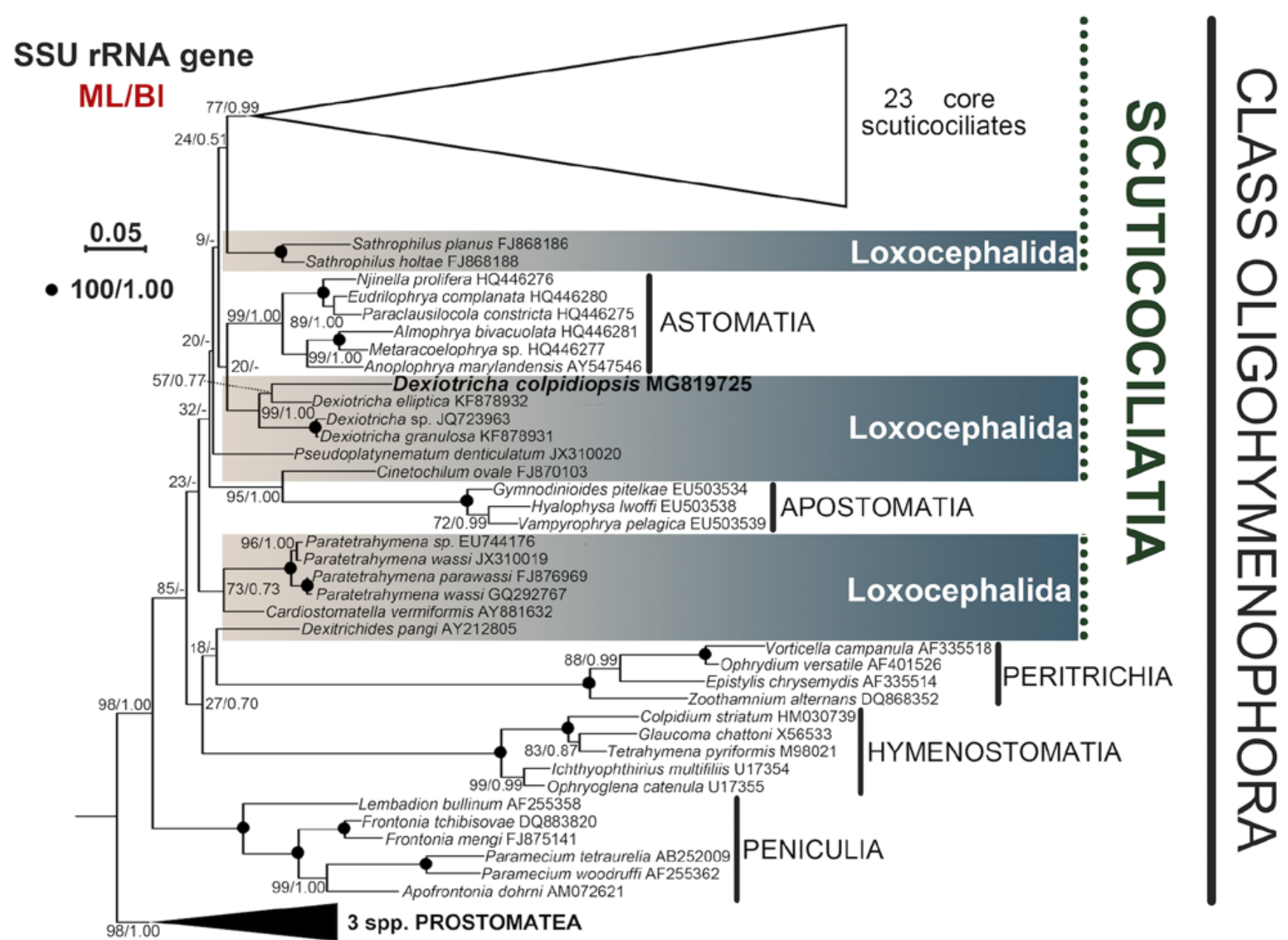

Fig. 4. Phylogenetic tree inferred by Maximum-likelihood (ML) analyses of the small SSU rRNA gene sequences. The new sequence is highlighted in bold. Numbers at the nodes are the bootstrap values of the ML and BI analyses, respectively. The mark "-“ indicates discrepancies in the topologies of the ML and BI trees; thus, only the values of ML are shown in these cases. The scale bar corresponds to 5 substitutions per 100 nucleotide positions.

Based on the descriptions by Augustin and Foissner (1992) and Jankowski (1964), the separation of Dexiotricha tranquilla and D. raikovi is uncertain concerning the size of live cells (30-60 $\mu \mathrm{m}$ in D. tranquilla vs. ca. $50 \mu \mathrm{m}$ in D. raikovi), the number of somatic kine- ties (20-24 vs. $20-22)$, and the positions of contractile vacuole and macronucleus (mid-body); the only clear difference is found in the number of postoral kineties (three in D. raikovi vs. two in D. tranquilla). Likewise, $D$. granulosa and D. media are hardly distinguished; 
the only obvious difference might be the presence of ring-like granules in the cytoplasm of $D$. granulo$s a$, while these structures had not been mentioned in D. media (Peck 1974; Foissner et al. 1994). Accordingly, future redescriptions based on morphology and barcoding are required for a reliable decision about their conspecificity.

Comparison of specimens from Iceland with original description and authoritative redescriptions (Table 3). The species was originally described by Kahl (1926) from a slurry pit under the name Loxocephalus colpidiopsis, with a short and insufficient description based on live observations (Fig. 2B). Jankowski (1964) redescribed the species and transferred it to the genus Dexiotricha Stokes, 1885. He also suggested Loxocephalus enigmaticus Vuxanovici, 1960 as junior synonym of the species. Our isolate fits the original description given by Kahl (1926) as well as the redescription by Jankowski (1964) in all diagnostic characteristics provided by these authors, i.e., cell size and shape in vivo, number of somatic kineties, caudal cilia, and postoral kineties, and positions of macronu- cleus and contractile vacuole. While the transverse row of cilia was neither mentioned by Kahl (1926) nor by Jankowski (1964), it is visible in an illustration provided by Kahl (1926) (Fig. 2B), and an oblique furrow in the right anterior cell portion extending to the oral apparatus was mentioned by Kahl (1931). The only clear difference between the previous records and the present specimens is the extreme habitat in which the encysted Iceland specimens had been discovered; the specimens are able to survive in the encysted state at $75^{\circ} \mathrm{C}$ at the sampling site, and grow at $20^{\circ} \mathrm{C}$; they can be cultivated in both water from sampling site as well as Volvic water. Since the species excysted and grew well at room temperature, which does not distinctly deviate from the temperatures prevailing at the other sampling sites, identification as D. colpidiopsis is reasonable. High abundances of bacteria seem to be pivotal for the growth of $D$. colpidiopsis.

Fauré-Fremiet (1968) reported a population of D. colpidiopsis (Fig. 5J) with approximately 34 somatic kineties (vs. 20-24 in Jankowski's and our isolates). The combination of features (macronucleus and contractile
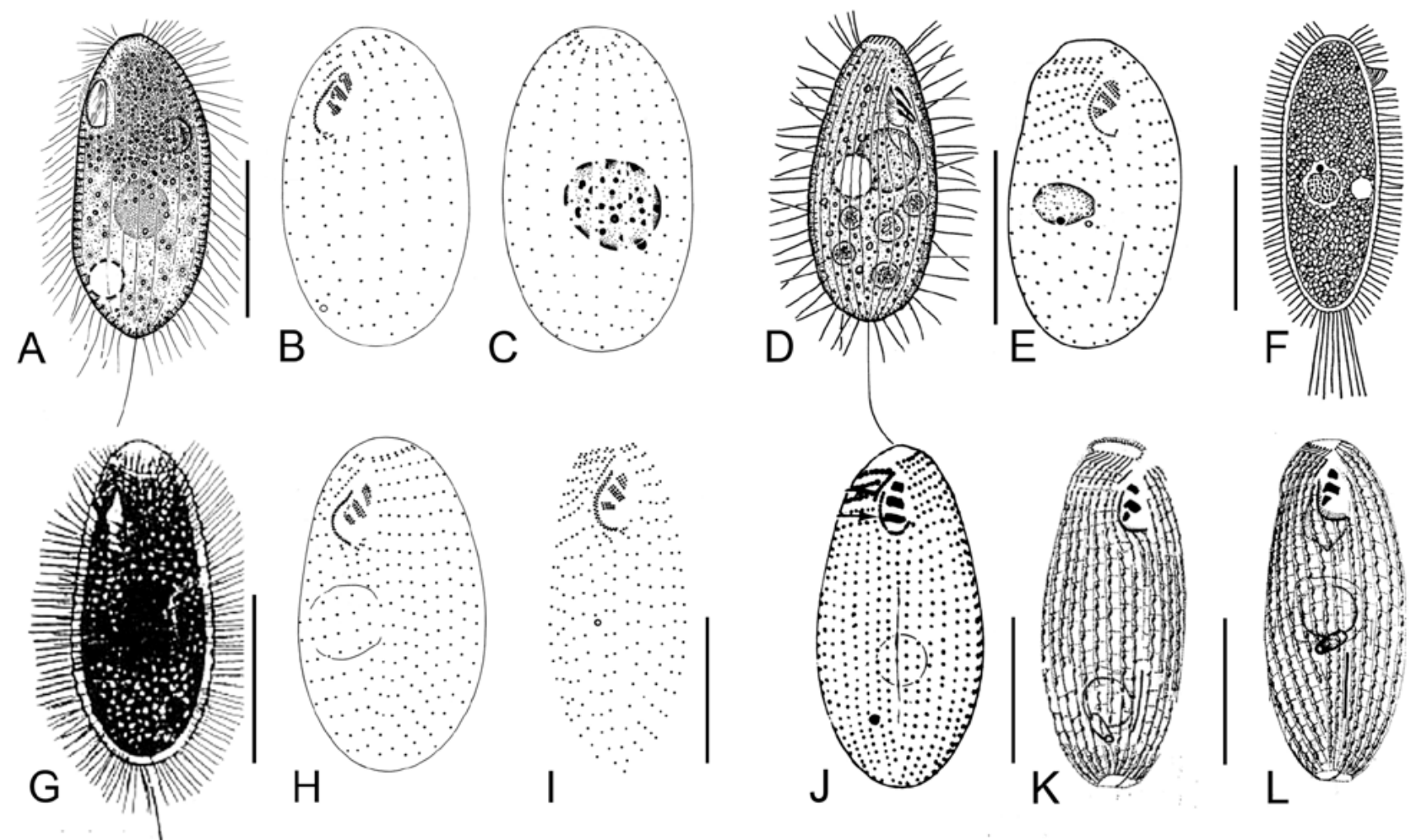

Fig. 5. Dexiotricha species from live (A, D, F, G) and silver-stained specimens (B, C, E, H-L). (A-C) D. elliptica (from Fan et al. 2014). (D, E) D. tranquilla (from Augustin and Foissner 1992). (F) D. polystyla (from Foissner 1987). (G, H) D. granulosa (G from Behrend 1916; H from Fan et al. 2014). (I) D. media (from Peck 1974). (J, K) D. colpidiopsis (J from Fauré-Fremiet 1968; H from Jankowski 1964). (L) D. raikovi (from Jankowski 1964). Scale bars: $20 \mu \mathrm{m}$. 
vacuole in posterior cell half, large number of somatic kineties) makes Fauré-Fremiet's isolate unique, indicating that it might represent a new morphospecies. This remains to be verified.

Comparison with congeners (Table 3). Based on the body size of live cells, the number of caudal cilia, and the positions of macronucleus and contractile vacuole, D. colpidiopsis matches D. elliptica. However, the two species can clearly be distinguished by the number of somatic kineties (24-27 vs. 16) (Fan et al. 2014).

Dexiotricha colpidiopsis, D. media, and D. granulosa are similar in cell size in vivo. The former two species can be distinguished from $D$. granulosa by the absence of the ring-shaped cytoplasmic granules (vs. presence). D. colpidiopsis differs from the latter two by the positions of macronucleus and contractile vacuole (in posterior cell third vs. mid-body), and number of somatic kineties (24-27 vs. 30-38) (Jankowski 1964; Peck 1974; Wilbert 1986; Foissner et al. 1994).

Dexiotricha cf. granulosa sensu Fan et al. (2014) is very similar to the Iceland specimens of $D$. colpidiopsis in all main characteristics, e.g., cell size in vivo, number of somatic kineties, as well as the positions of macronucleus and contractile vacuole. However, the presence of ring-shaped cytoplasmic granules in the specimens studied by Fan et al. (2014) contradicts the conspecificity with $D$. colpidiopsis, and justifies maintenances of their isolate as $D$. cf. granulosa.

Although the ciliary pattern of Dexiotricha polystyla is still unknown, it can clearly be distinguished from $D$. colpidiopsis by the number of its caudal cilia (multiple vs. one) and the positions of macronucleus and contractile vacuole (in mid-body vs. posterior third of cell) (Foissner 1987).

Dexiotricha raikovi can be separated from $D$. colpidiopsis by fewer somatic kineties (20-22 vs. 24-27) and the positions of macronucleus and contractile vacuole (in mid-body vs. posterior cell third) (Jankowski 1964).

Dexiotricha tranquilla differs from $D$. colpidiopsis in the numbers of somatic (22 vs. 24-27) and postoral kineties (two vs. three) as well as in the positions of macronucleus and contractile vacuole (in mid-body vs. posterior third of cell) (Jankowski 1964; Augustin and Foissner 1992).

Occurrence of Dexiotricha colpidiopsis. The species had originally been described from a slurry pit (Kahl 1926) and later also from freshwater (Jankowski 1964; Taylor and Berger 1980), soil (Peck 1974), and activated sludge samples (Madoni and Ghetti 1981). Here, for the first time viable resting cysts had been collected from a geothermal environment. Thus, our finding broadens the range of habitats in which this ciliate species occurs. A possible explanation for the wide distribution of $D$. colpidiopsis are the obviously high eurythermy of its resting cysts and the ability to generate high abundances under common culture conditions; both characteristics increase their dispersal capabilities driven by natural forces such as wind circulation patterns, precipitation or migrating animals (Finlay 2002).

It is not the chemical composition (with high concentration of ions; Table 1) of the water at the sampling site which makes this habitat special, but its high temperature of ca. $75^{\circ} \mathrm{C}$. Even so Dexiotricha colpidiopsis occurred only in encysted state under such conditions, its resting cysts were viable, i.e., the ciliates excysted in the culture and grew very well, demonstrating a high heat tolerance. Actually, only ciliates from a small number of genera have been reported to dwell in hot springs with temperatures of more than $40^{\circ} \mathrm{C}$ (reviewed in $\mathrm{Hu}$ 2014) or deep-sea hydrothermal vent sites (Small and Gross 1985): Trimyema minutum (up to $52^{\circ} \mathrm{C}$; Baumgartner et al. 2002), Oxytricha fallax $\left(56^{\circ} \mathrm{C}\right.$; Uyemura 1936), and Cyclidium spp. $\left(58^{\circ} \mathrm{C}\right.$; Kahan 1972). To the best of our knowledge, $68^{\circ} \mathrm{C}$ is the maximum temperature at which growth in a ciliate was recorded, namely in a Chilodonella species (Dombrowski 1961). Therefore, the viability of the resting cysts in $D$. colpidiopsis from the geothermal habitat in Iceland broadens our knowledge on ciliate's abilities to survive under extreme environmental condition.

Establishment of neotype. The neotype is designated following the ICZN (1999). Although Jankowski (1964) performed silver staining, he did not mention the deposition of type material in his publication. After detailed investigations, we did not find any slide collection with Jankowski's slide preparation of Dexiotricha colpidiopsis. Therefore, it is reasonable to assume that permanent slides of Dexiotricha colpidiopsis from Jankowski (or any other author) are unavailable. Because of the problematic taxonomy within the genus Dexiotricha (see above), the designated neotype will contribute to taxonomic and nomenclatural stability. The identification is beyond reasonable doubt (see comparison with original description and authoritative redescriptions). The specimens collected at the hot spring in Iceland only occurred in encysted state and could successfully be cultivated at room temperature. This matches the environmental conditions of the original type locality as mentioned in Kahl (1926). The same applies to the chemical composition of the water 
(hot spring water and Volvic vs. slurry pit). Also, a high abundance of bacteria in its environment seems typical for the species as inferred from the previous records and the present data.

Phylogenetic relationships (Fig. 4). Our phylogenetic analyses are congruent with previous studies showing the non-monophyly of the order Loxocephalida (Gao et al. 2013). Besides the new SSU rRNA gene sequence of Dexiotrich a colpidiopsis, only three further sequences of congeners are currently available. The SSU rRNA gene of $D$. colpidiopsis is clearly distinct from the genes of these three species (Table 4). The sister group relationship of $D$. colpidiopsis and D. elliptica is corroborated by their morphological similarity (see discussion above). Additionally, the analyses of the Dexiotricha SSU rRNA gene sequences suggest a monophyly of the genus. For elucidating the relationships among the seven Dexiotricha, taxon sampling must be increased and possibly further marker genes have to be analysed. By combining morphological, molecular, and ecological features, the present description follows the recommendations of Warren et al. (2017), providing a more reliable species circumscription that facilitates identification.

Acknowledgments. This study was funded by grants awarded to TS by Europlanet 2020 (project 15-EPN-006) and by the Bundesministerium für Bildung und Forschung (BMBF)/Deutsches Zentrum für Luft- und Raumfahrt (DLR, grant 50WB1737). Europlanet 2020 RI has received funding from the European Union's Horizon 2020 research and innovation programme under grant agreement No 654208. Zhishuai Qu received funds from the China Scholarship Council (CSC). We thank Fengchao Li for his support with species identification and Natasa Desnica (Matis) for the trace metal analysis.

\section{REFERENCES}

Agatha S., Wilbert N., Spindler M., Elbrächter M. (1990) Euplotide ciliates in sea ice of the Weddell Sea (Antarctica). Acta Protozool. 29: 221-228

Agatha S., Spindler M., Wilbert N. (1993) Ciliated protozoa (Ciliophora) from Arctic sea ice. Acta Protozool. 32: 261-268

Augustin V. H., Foissner W. (1992) Morphology and ecology of some ciliates (Protozoa: Ciliophora) from activated sludge. Arch. Protistenk. 141: 243-283

Baumgartner M., Stetter K. O., Foissner W. (2002) Morphological, small subunit rRNA and physiological characterization of Trimyema minutum (Kahl, 1931), an anaerobic ciliate from submarine hydrothermal vents growing from $28^{\circ} \mathrm{C}$ to $52^{\circ} \mathrm{C}$. $J$. Eukaryot. Microbiol. 49: 227-238

Behrend K. (1916) Zur Conjugation von Loxocephalus. Arch. Protistenkd. 37: 1-5
Djokic T., Van Kranendonk M. J., Campbell K. A., Walter M. R., Ward C. R. (2017) Earliest signs of life on land preserved in ca. 3.5 Ga hot spring deposits. Nat. Commun. 8: 15263

Dragesco J., Dragesco-Kernéis A. (1986) Ciliés libres de l'Afrique intertropicale: introduction à la connaissance et à l'étude des Ciliés. IRD Editions

Dombrowski H. (1961) Methoden und Ergebnisse der Balneobiologie. Therap. Gegenw. 100: 442-449

Fan X., Al-Farraj S. A., Gao F., Gu F. (2014) Morphological reports on two species of Dexiotricha (Ciliophora, Scuticociliatia), with a note on the phylogenetic position of the genus. Int. J. Syst. Evol. Microbiol. 64: 680-688

Fauré-Fremiet E. (1968) Les genres Dexiotricha Stokes et Loxocephalus Eberhard dans leurs relations auxomorphiques. Protistologica 4: 115-125

Filker S., Forster D., Weinisch L., Mora-Ruiz M., González B., Farías M., Rosselló-Móra R., Stoeck T. (2017) Transition boundaries for protistan species turnover in hypersaline waters of different biogeographic regions. Environ. Microbiol. 19: $3186-3200$

Finlay B. J. (2002) Global dispersal of free-living microbial eukaryote species. Science 296: 1061-1063

Foissner W. (1987) Neue terrestrische und limnische Ciliaten (Protozoa, Ciliophora) aus Österreich und Deutschland. Sber. Akad. Wiss. Wien 195: 217-268

Foissner W. (2012) Schmidingerothrix extraordinaria nov. gen., nov. spec., a secondarily oligomerized hypotrich (Ciliophora, Hypotricha, Schmidingerotrichidae nov. fam.) from hypersaline soils of Africa. Eur. J. Protistol. 48: 237-251

Foissner W. (2014) An update of 'basic light and scanning electron microscopic methods for taxonomic studies of ciliated protozoa'. Int. J. Syst. Evol. Microbiol. 64: 271-292

Foissner W., Agatha S., Berger H. (2002) Soil ciliates (Protozoa, Ciliophora) from Namibia (Southwest Africa), with emphasis on two contrasting environments, the Etosha region and the Namib Desert. Part I: Text and line drawings. Part II: Photographs. Denisia 5: 1-1459

Foissner W., Berger H., Kohmann F. (1994) Taxonomische und ökologische Revision der Ciliaten des Saprobiensystems - Band III: Hymenostomata, Prostomatida, Nassulida. Informationsber. Bayer. Landesamtes Wasserwirtsch. Heft 1/94: 1-548

Foissner W., Filker S., Stoeck T. (2014) Schmidingerothrix salinarum nov. spec. is the molecular sister of the large oxytrichid clade (Ciliophora, Hypotricha). J. Eukaryot. Microbiol. 61: 61-74

Gao F., Katz L. A., Song W. (2013) Multigene-based analyses on evolutionary phylogeny of two controversial ciliate orders: Pleuronematida and Loxocephalida (Protista, Ciliophora, Oligohymenophorea). Mol. Phylogenet. Evol. 8: 55-63

Gao F., Warren A., Zhang Q., Gong J., Miao M., Sun P., Song W. (2016) The all-data-based evolutionary hypothesis of ciliated protists with a revised classification of the phylum Ciliophora (Eukaryota, Alveolata). Sci. Rep. 6: 24874

$\mathrm{Hu}$ X. (2014) Ciliates in extreme environments. J. Eukaryot. Microbiol. 61: $410-418$

ICZN [The International Commission on Zoological Nomenclature]. (1999) International Code of Zoological Nomenclature. Fourth edition adopted by the International Union of Biological Sciences. International Trust for Zoological Nomenclature, London

Jankowski A. W. (1964) Morphology and evolution of Ciliophora. IV. Sapropelebionts of the family Loxocephalidae fam. nova, their taxonomy and evolutionary history. Acta Protozool. 2: 33-58 
Jankowski A. W. (2007) Phylum Ciliophora Doflein, 1901. In: Alimov AF. (ed) Protista, Part 2. NAUKA, St. Petersburg, pp. 415-993

Kahl A. (1926) Neue und wenig bekannte Formen der holotrichen und heterotrichen Ciliaten. Arch. Protistenk. 55: 197-438

Kahl A. (1931) Urtiere oder Protozoa I: Wimpertiere oder Ciliata (Infusoria). 2. Holotricha. Tierwelt Dtl. 21: 181-398

Kahan D. (1969) The fauna of hot springs. Verh. Int. Verein Limnol. 17: $811-816$

Kahan D. (1972) Cyclidium citrullus Cohn, a ciliate from the hot springs of Tiberias (Israel). J. Protozool. 19: 593-597

Kouris A., Juniper S. K., Frebourg G., Gaill F. (2007) Protozoanbacterial symbiosis in a deep-sea hydrothermal vent folliculinid ciliate (Folliculinopsis sp.) from the Juan de Fuca Ridge. Mar. Ecol. 28: 63-71

Liu W., Jiang J., Xu Y., Pan X., Qu Z., Luo X., El-Serehy H. A., Warren A., Ma H., Pan, H. (2017) Diversity of free-living marine ciliates (Alveolata, Ciliophora): faunal studies in coastal waters of China during the years 2011-2016. Eur. J. Protistol. 61: $424-438$

López-García P., Rodríguez-Valera F., Pedrós-Alió C., Moreira D. (2001) Unexpected diversity of small eukaryotes in deep-sea Antarctic plankton. Nature 409: 603-607

Madoni P., Ghetti P. F. (1981) The structure of ciliated protozoa communities in biological sewage-treatment plants. Hydrobiologia 83: 207-215

Miller M. A., Pfeiffer W., Schwartz T. (2010) Creating the CIPRES Science Gateway for inference of large phylogenetic trees. Paper presented at the Gateway Computing Environments Workshop (GCE), New Orleans, LA, USA, 14 November 2010, pp. 1-8

Noland L. E., Gojdics M. (1967) Ecology of free-living protozoa. In: Research in Protozoology, Chen T. T., Ed. (Oxford, Pergamon), vol. 2. chap. 4

Nylander J. (2004) MrModeltest v2. Program distributed by the author. Evolutionary Biology Centre, Uppsala University

Oren A. (2002) Diversity of halophilic microorganisms: Environments, phylogeny, physiology, and applications. J. Ind. Microbiol. Biotechnol. 28: 56-63

Pan X., Bourland W. A., Song W. (2013) Protargol synthesis: an inhouse protocol. J. Eukaryot. Microbiol. 60: 609-614

Peck R. K. (1974) Morphology and morphogenesis of Pseudomicrothorax, Glaucoma and Dexiotricha with emphasis on the types of stomatogenesis in holotrichous ciliates. Protistologica 10: $333-370$

Petz W., Song W., Wilbert N. (1995) Taxonomy and ecology of the ciliate fauna (Protozoa, Ciliophora) in the endopagial and pelagial of the Weddell Sea, Antarctica. Stapfia 40: 1-223

Posada D., Crandall K. A. (1998) Modeltest: testing the model of DNA substitution. Bioinformatics 14: 817-818

Roberts E. C., Priscu J. C., Wolf C., Lyons B., Laybourn-Parry J. (2004) The distribution of microplankton in the McMurdo Dry Valley Lakes, Antarctica: response to ecosystem legacy or present-day climatic control? Polar Biol. 27: 238-249
Ronquist F., Huelsenbeck J. P. (2003) MrBayes 3: Bayesian phylogenetic inference under mixed models. Bioinformatics 19: $1572-1574$

Stoeck T., Hayward B., Taylor G. T., Varela R., Epstein S. S. (2006) A multiple PCR-primer approach to access the microeukaryotic diversity in environmental samples. Protist 157: 31-43

Small E. B., Gross M. E. (1985) Preliminary observations of protistan organisms, especially ciliates from the $21^{\circ} \mathrm{N}$ hydrothermal vent site. Biol. Soc. Washington Bull. 6: 401-410

Song W., Warren A., Hu X. (2009) Free-living ciliates in the Bohai and Yellow Seas. 1st ed. Science Press, Beijing, p. 1-518

Stamatakis A. (2014) RAxML version 8: a tool for phylogenetic analysis and post-analysis of large phylogenies. Bioinformatics 30: $1312-1313$

Stokes A. C. (1885) Notes on some apparently undescribed forms of fresh-water Infusoria. No. 2. Am. J. Sci. 29: 313-328

Taylor W. D., Berger J. (1980) Microspatial heterogeneity in the distribution of ciliates in a small pond. Microbial. Ecol. 6: 27-34

Uyemura M. (1936) Biological studies of thermal waters in Japan. IV. Ecol. St. 2: 171

Vuxanovici A. (1960) Noi contributii la studiul ciliatelor dulcicole din Republica Populara Romina (nota 1). Stud. Cercet. Biol. 12: 353-381

Warren A., Patterson D. J., Dunthorn M., Clamp J. C., Achilles-Day U. E. M., Aescht E., Al-Farraj S. A., Al-Quraishy S., Al-Rasheid K., Carr M., Day J. G., Dellinger M., El-Serehy H. A., Fan Y., Gao F., Gao S., Gong J., Gupta R., Hu X., Kamra K., Langlois G., Lin X., Lipscomb D., Lobban C. S., Luporini P., Lynn D. H., Ma H., Macek M., Mackenzie-Dodds J., Makhija S., Mansergh R. I., Martín-Cereceda M., McMiller N., Montagnes D. J. S., Nikolaeva S., Ong'ondo G. O., Pérez-Uz B., Purushothaman J., Quintela-Alonso P., Rotterová J., Santoferrara L., Shao C., Shen Z., Shi X., Song W., Stoeck T., LaTerza A., Vallesi A., Wang M., Weisse T., Wiackowski K., Wu L., Xu K., Yi Z., Zufall R., Agatha S. (2017) Beyond the "code": a guide to the description and documentation of bio-diversity in ciliated protists (Alveolata, Ciliophora). J. Eukaryot. Microbiol. 64: 539-554

Wilbert N. (1975) Eine verbesserte Technik der Protargolimprägnation für Ciliaten. Mikrokosmos 64: 171-179

Wilbert N. (1986) Ciliaten aus dem interstitial des Ontario Sees. Acta Protozool. 25: 379-396

Xu Y., Shao C., Fan X., Warren A., Al-Rasheid K. A. S., Song W., Wilbert N. (2016) New contributions to the biodiversity of ciliates (Protozoa, Ciliophora) from Antarctica, including a description of Gastronauta multistriata n. sp. Polar Biol. 39: $1439-1453$

Received on $26^{\text {th }}$ January, 2018; revised on $28^{\text {th }}$ March, 2018; accepted on $11^{\text {th }}$ April, 2018 